6. Collins, E. T.-Observations on Ring Infiltration of the Cornea. Ophthal. Review, Vol. XII, 1893, p. 221.

7. Fuchs, E.-Ueber Ringabscess der Hornhaut. Arch. f. Ophthal., 1903, V.ol. LVI, pp. I 3 (case vi.), 27, 28, 29.

8. Parsons, J. H.-Pathology of the Eye : Peripheral Annular Infiltration of the Cornea, p. 217.

9. Leber, T.-Bowman Lecture-On the Present P'osition of our Knowledge of Inflammation. Trans. Ophthal. Soc. U.K., Vol. XII, 1892, pp. I1, 12, I3, I4, 22,

Io. Muir, R. and Ritchie, G. - "Manual of Bacteriology," 1913. Immunity, p. 549.

I I. Fuchs, E.- "Lehrbuch der Augenheilkunde." Twelfth edition, I9Io. Keratitis disciformis, p. 270.

12. Fuchs, E. - Ueber Knötchenförmige Hornhauttrübung. Arch. f. Oththal., Vol. LXXXIX, second number, February, 1915, p. 337.

\title{
HERPES ZOSTER AFFECTING THE CILIARY NERVES*
}

\author{
BY \\ George W. Thompson, F.R.C.S. \\ LONDON
}

HERPETIC eruptions on the sclera may occur in the course of severe attacks of herpes zoster ophthalmicus affecting the branches of the first division of the fifth nerve, including its nasal branch, and are usually associated with such changes as herpetic vesicles of the cornea, keratitis striata, "keratitis punctata," and iritis. The efflorescences take the form either of small, reddish nodules, or of larger nodules, the centre of which is transparent, or even resembles a limpid vesicle. They usually appear about a fortnight after the corneal disturbances have declared themselves, and persist for one or two months longer than the latter. They eventually clear up, leaving a slight discolouration of the sclera, and an adhesion of the overlying conjunctiva. It is important that the underlying cause, be it syphilis, influenza, or nasal or dental trouble, be treated. When the acute manifestations have subsided under fomentations and atropin, yellow ointment with dionin should be employed, with a view to clearing up the scleral nodules.

The following four cases have been met with :-

Case No. 1.-A male patient, aged 41, suffered from left herpes zoster ophthalmicus, affecting most of the branches of the first division of the fifth nerve, on the day after his nose had been forcibly washed out by a throat specialist. When seen by me, ten days later, there were signs of herpes and anaesthesia on the left side of the nose, two small erosions on the upper part of the cornea, and typical "keratitis punctata"; and three days later keratitis striata was observed for the first time. Twenty-one days after the

*Abstract of a communication read at the 1918 Congress of the Ophthalmological Society of the United Kingdom. 
patient was first examined by me, a large, raised, vascular boss, not tender, was present in the upper and inner quadrant of the sclera, in contact with the edge of the cornea. Eleven weeks later the nodule had disappeared, leaving a slight discolouration at its site. At a later period a specific history was obtained, and the Wassermann reaction was found to be positive.

Case No. 2.-A female, aged 36, was seen two months after herpes zoster on the right side of the head, with eye complications coming on a few days later. The right side of the patient's forehead was covered with post-herpetic scars; the cornea, the sensibility of which was somewhat diminished, presented the scars of an herpetic eruption, and there were two swellings, each about the size of a large split pea, in the lower half of the sclera. About one month later one of the swellings had almost disappeared, and the other was smaller.

Case No. 3.-A male, aged 66, had an attack of severe herpes on the right side, and fourteen days later cutaneous red patches in relation to the branches of the first division of the fifth nerve, including the nasal branch. The skin and the cornea were painful and tender. The lower half of the last-named was cloudy from keratitis striata and "keratitis punctata." The iris was injected. There were three reddish swellings on the sclera. All the conditions made a satisfactory, although rather slow, recovery. During the course of treatment the hypertrophied middle turbinal bodies were treated with the electric cautery.

Case No. 4.-A female, aged 57, suffered from intense pain down the left side of the nose and forehead, radiating into the left ear and back of neck; had many small red areas on the skin of the left frontal region, and oedema of the inner end of the left upper eyelid, and a large patch of conjunctival injection on the nasal side of the cornea. A week later she developed vesicles along the branches of the first division of the fifth nerve, including the nasal branch. Five months later the cornea presented three opacities (healed vesicles), and there were two small, raised, rounded, reddish patches with discoloured centres on the nasal side of the sclera, not far from the edge of the cornea. Ten months later there was only a slight discolouration of the sclera near the cornea.

\section{ANNOTATIONS}

\section{Opticians and National Service}

A case which is of considerable interest to medical men in general and to ophthalmic surgeons in particular, has been recently argued before the Appeal Tribunal in Jersey. A local paper reports the hearing 